\title{
Task-Technology Fit Model: The Factors Affecting Students' Academic Performance in Higher Education
}

\author{
Ali Mugahed Al-Rahmi, ${ }^{1, *}$, Alina Shamsuddin ${ }^{1}$, Omar A Alismaiel ${ }^{2}$ \\ ${ }^{1}$ Faculty of Technology Management and Business, Universiti Tun Hussein Onn Malaysia, Johor, Malaysia \\ ${ }^{2}$ College of Education, Educational Technologies, King Faisal University, Alhasa, Saudi Arabia
}

Received July 24, 2020; Revised October 29, 2020; Accepted November 11, 2020

\section{Cite This Paper in the following Citation Styles}

(a): [1] Ali Mugahed Al-Rahmi, Alina Shamsuddin, Omar A Alismaiel, "Task-Technology Fit Model: The Factors Affecting Students' Academic Performance in Higher Education," Universal Journal of Educational Research, Vol. 8, No. 12, pp. 6831 - 6843, 2020. DOI: 10.13189/ujer.2020.081249.

(b): Ali Mugahed Al-Rahmi, Alina Shamsuddin, Omar A Alismaiel (2020). Task-Technology Fit Model: The Factors Affecting Students' Academic Performance in Higher Education. Universal Journal of Educational Research, 8(12), 6831 - 6843. DOI: 10.13189/ujer.2020.081249.

Copyright $\bigcirc 2020$ by authors, all rights reserved. Authors agree that this article remains permanently open access under the terms of the Creative Commons Attribution License 4.0 International License

\begin{abstract}
This paper mitigates the variation in literature on the usage in Behavioural Purpose to use and actual social media use through social media use and also it influences performance and satisfaction of students at higher education. Thus, this research aimed to develop a model to investigate along with behavioral intention to use and actual social media that influence students' satisfaction and performance impact use task technology fit (TTF) model. A questionnaire survey on Task-technology fit theory was circulated among a total of 206 university students as the key method for collecting data. This research hypothesizes that social characteristics and technology characteristics can affect the task technology fit, which also hypothesizes TTF for behavioral intention to use and actual social media that turn to improve students' satisfaction, and performance impact. However, all research findings were attained through a quantitative method using the Structural Equation Modeling (SEM-AMOS). Findings out in this research indicate positive effect students on their academic through behavioral intention to utilize of social media for teaching and learning in higher education. Moreover, the results that social media is used for learning purpose and enables sharing of knowledge, discussions, and information to enhance students' learning activities, therefore, we recommend students to use social media for educational purposes through lecturers at higher education institutions.
\end{abstract}

Keywords Task-Technology, Social Media, Social Characteristics, Students' Performance Impact,
Technology Characteristics

\section{Introduction}

Social media sites represent recent innovation, which was intended to foster large-scale collaboration and communication. Since their invention, such sites have spread so rapidly that daily users are growing, and an integral part of people personal and professional lives [1]. Social media can be defined as a group of Internet-based an application that build on the ideological and technological foundations of Web 2.0, and allows the creation and interchange of information [2]. The term social media refers to group of tools including blogging services, discussion forums, and wikis. Thus, the overarching concept of social media entirely contains social networking sites, which [1] defined as "an online service that allows users to build public or private profile to link their social connections and interaction with them. For the sake of clarity and consistency, the term social media will be used hereafter to refer exclusively through social networking sites. [3, 4] Many studies have reported positive impacts of integrating social media sites in higher education technology resources. Many such studies were aimed at students. It is important to be careful when they use social media, especially in education. While ignoring social media together is not recommended people, it should still 
understand the negative effects that it has affected on society [5]. The use of social media for academic purposes was not significant predictor that measured of academic performance by a cumulative grade point average, but the academic performance was negatively predicted using social media for non-academic purposes and social media multitasking [6]. Although there is wide range of studies on actual social media use aimed to explore influencing factors, there is a lack of comprehension of the social media network that integrates all essential factors on actual social media to influence student's performance in study [7, 8]. Much research has done on social media networks. In recent years, new streams of research in this area beginning to focus on the use of social media, nevertheless, there is a lack of studies. [7][9] have conducted research to understand the use of social media as effective teaching and learning tools through active collaborative learning in higher education and it does in order to raise the quality of learning in higher education institutions. To date, it has focused using social media placed in developed countries such as the US, Australia and the UK highlighted the importance of the appropriateness of task technology (TTF) in the evaluation of IS success. According to a model of D\&M Goodhue and Thompson (1995) technology performance to chain based on attitudinal and behavioral theories (i.e., planned behavior theories) and suitability theories. They argued that performance impact (i.e., execution of a task) are determined by use (i.e., use of technology) and task technology fit (TTF) [10]. TTF refers to how technology meets the need of users' task and it is a function of task characteristics, technology characteristics, and individual characteristics. [11] Students can use their information enabled in the system to promote learning. Therefore, the availability of information and/or the system may reflect the dimension static adaptation. In such a context of the information system, human to cooperates common goal in learning. Previous studies have suggested that perceived TTF is associated with use in learning systems involving knowledge sharing, collection, analysis or construction [12]. Problem-solving assists individual building their own unique experience and expertise to find a solution and as soon as they extract all unique lessons [13]. The meaning of Task-technology fit theory is seen as cognitive activity that produces mental perceptions that reflect models of reality. In general, Task-technology fit theory aims to identify how learning processes and applied in social media use, and how knowledge is constructed. Therefore, this study aims to develop a model that measures the social media use to determine the level of students' Social characteristics, Technology characteristics, and Task-Technology Fit through behavioral intention and
Actual social media to increase students' satisfaction and academic performance.

\subsection{Problem Statement}

The use of social media led to academic difficulties [14, 15]. Use of social media influences Student Grade Point Average (GPA) and academic performance [16, 17]. Research students use social media in learning which has a negative impact on concentration [18]. According to [19] observation time selected to use social media tools intended for social purposes was not used for educational purposes. Accordingly, a negative effect was seen on the educational performance of students [20, 21]. In addition, there are many social media models there are a limited number of models for assessing research student performance and satisfaction through Task-technology fit theory. Therefore, the research gap concerns the negative of reflection on actual social media use with consideration of relevant Task-technology fit factors [22]. Practical instrument models measure such factors in such a context in a single study and focus on negative effects [23, 24]. There is a lack of intention on social media actual use and how this affects students' performance by considering relevant Task-technology fit factors [22]. In addition, there is a lack of models that have researched understanding of actual social media use and how it affects students' performance in Malaysian higher education $[25,26,27]$. Therefore, the main objective of our study is to overcome these weaknesses by developing a model with constructivism, quality of education and social media use factors in the context of Malaysian higher education through the task-technology fit theory.

\section{Theoretical Model and Hypotheses}

The theoretical model of task technology fit (TTF) is widely used to evaluate how information technology produces performance, assess usage impacts, and match the task to the technology characteristics. The appropriateness of task technology and task characteristics can be affected which in turn determines user performance and usage [28]. all aspect factor models in this research of task-technology fit social characteristics, technology characteristics, task-technology fit, behavioral intention to use, and actual social media use. The model includes that content of social characteristics, technology characteristics, task-technology fit, behavioral intention to use, and actual social media use, student satisfaction, and performance impact, which consequently affect student's academic performance at higher academic institutes. (see Figure. 1). 


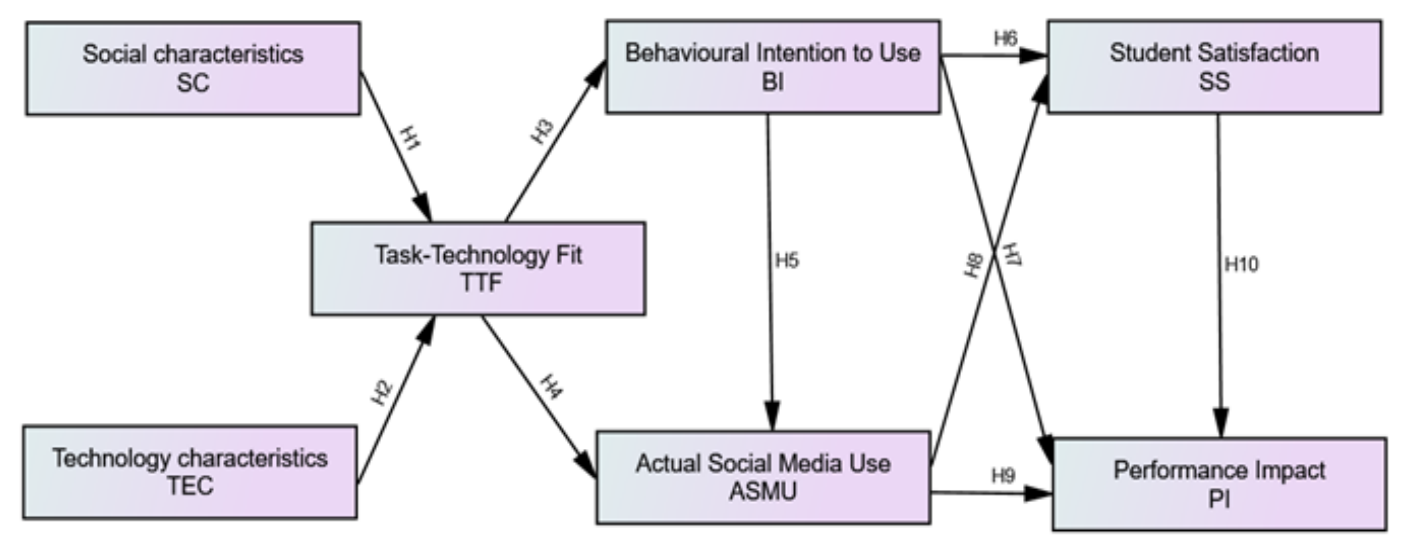

Figure 1. Research Model

\subsection{Technology Characteristics}

The framework can explained Social media by seven functional building blocks: identity, conversations, sharing, presence, relationships, reputation, and groups [36]. The TTF model is used to explain and predict widely how the mismatch between task requirements and technological applications positively affects task performance and technology utilized. The appropriateness of task technology can affect in turn determines user performance and usage. The extent of technology is suitable for tasks, which the features of the technology match the requirements of the task. The TAM addresses of beliefs and attitudes towards technology while the appropriateness of TTF model focus on technology characteristics and task characteristics [22]. Previous research has confirmed that technology characteristics are suitable to function for task technology [37].

\subsection{Task-Technology Fit}

TTF is used to examine how technology improves performance and TTF measures impact use of technology and assesses to match between the task and the technology features. Subsequently, researchers used the TTF extensively to predict adoption and using of new technology [38]. Although there are studies on TTF in a variety of contexts, there are very few studies on social media for instructor training in higher education. To date, it is unclear whether the TTF will affect student's acceptance for training and how well social media usage will impact student's acceptance. [39] Task-technology adaptation requires that information technology fit well with task it supports, to use it properly and to positively influence user performance. [40] Previous studies have used the TTF or incorporated it into other models. In this study, TTF refers to ability using of social media for learning to support students to apply their skills and competencies in a range of learning procedures, including the tutor-student interaction and access to resources and learning subject.

\subsection{Behavioral Intention to Use}

A behavioral intention is taken to capture the motivating factors that influence behavior; they are indicated how difficult of people are willing to experiment with the amount of effort they intend to behavior. Behavioral intention is determined as a proxy factor in users' acceptance and use of technology [41]. This study focuses on investigating factors that influence students' behavioral intention when using social media for purpose of collaborative learning. According to [42] Task-Technology-Fit (TTF) model was used as a performance predictor in a technology context. The basic principle is general of the TTF Model that if an information system fits well with tasks it supports; it will a positive impact on testing user performance. The behavioral intention effect significantly influences the actual use of the system (AU) of social media technology as demonstrated in various studies [43]. The respondents were found that social media used to enhance for learning a good idea as illustrated by the significant link between behavioral intention to use and actual use of social media for learning [44]. However, intention to use social media and actual use social media has relatively predicted low about students for learning. It seems to use Facebook to coincide with reported studies for academic purposes is low among students and lecturers, with students more open to using an idea $[45,46]$.

\subsection{Actual Social Media Use}

Actual usage is described to extent that person uses the functions of the information system, depending on the nature, frequency and duration of the specific technology. In term of Internet learning, actual usage is similar in terms of frequency, and duration of use $[47,48]$ extended the argument and revealed that user satisfaction, as well as social media usage has a significant impact on technology while focusing on shared quality view of information and technology quality. Social media effects on students' learning performance through prior Studies have shown 
that it was appropriate for their teachers to use Facebook by students and teachers can socialize [49]. In addition, both student's satisfaction and learning performance facilitate the use of social media positively [50]. Although an enormous ambit of studies on actual social media use aimed to explore influencing factors, there is a lack of studies about social media network that integrated all essential factors of actual social media to influence student performance in a study only [51]. Thus, Malaysian higher education will be able to conduct research on social media to integrate all factors associated with social media that are seen as a crucial step in understanding use of social media for students' impact on student performance.

\subsection{Student Satisfaction}

Satisfaction is defined as perception of individuals about what represent extent their needs, goals and desires are met [52]. According to [53] found that traditional education technologies affect student satisfaction through student involvement and education performance that social media practices reinforce these effects. The use of social media creates an easy relationship between "group members that explains their satisfaction from active collaborative learning and improves their learning performance". This also applied to the relationship between students and supervisors, where social media is instructed to exchange information and explanation [54]. It also makes it easy for me to share data and provide easy oncoming learning community, and to be satisfied with interaction using instructors to use social media, and to achieve a typical percentage for University students, as it provides educators with a more understandable form and academic success in higher education. In terms of satisfaction with using social media participation and achieving a higher percentage of student satisfaction for class participation, social media provides a lot of up-to-date content [55].

\subsection{Performance Impact}

Researchers defined both actual social media use and behavioral intention to use such as mediators variables in the investigation of factors influencing particular technologies [56]. As regard to intentions of social media use [57], it has shown in their studies using social media tools adversely affects social and non-social needs of social media and its impact on their academic performance. According to [58], a study in Hong Kong found that impact students using social media and social multitasking on academic performance, and also students claimed that use of social media for academic purposes was not a significant predictor academic performance. since the use of social media adversely affects academic performance for non-academic purposes [59]. This is attributable to increased stakeholder participation outside conventional classroom practices through the use of Twitter. In reality, the formation of social media groups such as Facebook has been found to promote student development [60]. The success of learning has an impact on social media across study areas. The findings, however, are some extraordinary cases that show a constructive partnership between Facebook and Twitter and convergence to increase learning. [61].

\section{Research Methodology}

In this article, our survey evaluated a sample of a prepared questionnaire of two specialists from University Tun Hussein Onn Malaysia (UTHM). In this article, collected data after UTHM has given me permission. This selected research model included social media users to train and communicate both gender groups of males and females through a questionnaire survey on (TTF) model as undergraduate and postgraduate students, and demographic data of obtained data were assessed applying of the different items was utilized of The Likert scale of 5- points, including elements. The "questionnaire was distributed to all respondents were asked to write their feedback on the use of social media for education and communication, and their opinions on its effect on academic performance. Data collected with SPSS, SEM-Amos and Structural Equation Modeling. SEM-Amos are regarded main statistical procedures used in our study involving two stages, the first phase is structural investigation, and second phase includes construction of the validity of the measures, the convergence validity of the measures, the discriminant validity of the measure this method was suggested by $[62$, 63].

\subsection{Sample Characteristics}

For the purposes of the study, we distributed 206 questionnaires, of which 206 were answered. After manual analysis of the questionnaires, all questionnaires were filled out. Usable questionnaires 54 were from "Female" $(26.2 \%)$ and $152(73.8 \%)$ from "Male". moreover, 11 respondents $(5.3 \%)$ were between 18 - 20 years old, 37 (18\%) were between 21-24 years old, 82 (39.8\%) were between 25 - 29 years old, $38(18,4 \%)$ ) were between 30 34 years old. 24 (11.7\%) were between 35 - 40 years old, 7 (3.4\%) were between 41 - 45 years old and 7 (3.4\%) were 46 years or older. The distribution of respondents based on specialization was as follows: 92 respondents were from Engineering (44.7\%), 46 respondents were from Management (22.3\%), 33 respondents were from science\& Technology $(13.9 \%), 24$ respondents were from social science $(11.7 \%), 8$ respondents were from Business Administration (3.9\%), and 1 respondent was from English literature $(0.5 \%)$. 


\subsection{Measurement Instruments}

The validity of the content of the measuring scales was confirmed by the construction elements used in previous studies. The questionnaire consisted of two parts: the questionnaire items, in which basic demographic data (gender, age, institutions and specialization) were collected, and the questionnaire items, which were measured as following; social characteristics (SC) was adapted 5 items from $[64,65,66,67]$, technology characteristics (TEC) was adapted 5 items from [68], task-technology fit (TTF) was adapted 5 items from [69], behavioral intention to use (BI) was adapted 5 items from [70,71], performance impact (PI) was adapted 5 items from [72,73], students' satisfaction (SS) was adapted to 6 items from $[74,10]$, and finally, actual social media use (ASMU) was adapted 6 items from $[7,51]$.

\section{Result and Analysis}

In this paper, associated factors influenced student satisfaction and performance. Considering behavioral intention to effective social media use, and also based on academic students' performance higher education with a Cronbach's reliability coefficient of 0.969 . Discriminant validity was assessed based on three conditions. The variable indices had to be less than 0.80 as recommended by [75]. Then, the equal to or more than 0.5 considered the value of average variance extracted "inter construct correlations (IC)" linked with factor is lower than the square average variance extracted (AVE)[76]. In addition, the construct's investigation gave a factor loading equal to composite reliability value equal or greater than 0.70 . Item and crematory factor value 0.7 or more and supposed to be acceptable, having Cronbach's Alpha [77].

\subsection{Measurement Model Analysis}

This study used SEM-Amos as a main statistical method for analyzing result based on confirmatory factor analysis (CFA) in AMOS 23. This model analyzed over convergent validity, uni-dimensionality, consistency and discriminant validity. In addition, Hair et al. [77] suggested that model evaluation should be considered through the process of estimating higher likelihood using well-adapted strategies such as "chi-square, normalized quoted square, normalized fit index (NFI), relative fit index (RFI) comparative fit and index (CFI), incremental fit index (IFI), parsimonious goodness fitness index (PGFI), and also mention of root mean square error of approximation (RMSEA) and mention of root mean square residual (RMR)" according to [77]. Table 1 provides a summary of the appropriate fit indices used to evaluate the models, for a mediator of measures and dependent variables, and Figure 3 is measurement task technology fit (TTF) Model.

Table 1. Summary of Goodness Fit Indices for the Measurement Model

\begin{tabular}{|c|c|c|}
\hline Type of measure & $\begin{array}{c}\text { Acceptable level of } \\
\text { fit }\end{array}$ & Values \\
\hline Root-Mean Residual (RMR) & Near to 0 (perfect fit) & .037 \\
\hline Normed Fit Index (NFI) & $>0.90$. & .928 \\
\hline Relative Fit Index (RFI) & $>0.90$. & .973 \\
\hline Incremental Fit Index (IFI) & $>0.90$. & .977 \\
\hline Tucker Lewis Index (TLI) & $>0.90$. & .952 \\
\hline Comparative Fit Index (CFI) & $>0.90$. & .947 \\
\hline $\begin{array}{c}\text { Root-Mean Square Error of } \\
\text { Approximation (RMSEA) }\end{array}$ & $<0.05$ indicates a \\
good fit. & .039 \\
\hline
\end{tabular}

\subsection{Measurement Model of Validity and Reliability}

Differential validity examines the level of evidence, which includes different indicators for different concepts [78]. Based on the obtained average variance extracted (AVE), all values exceeded 0.50 (cutoff) with a p-value of 0.001 , indicating that a different validity was agreed for each construct examined [77]. On the other hand, Hair et al. [77] described that the correlations of elements between constructions can only be a square root of the mean variance that they share in one of the constructions. In addition, the obtained composite reliability has been provided and the recommended value is obviously 0.70 or more. In addition, recommended value 0.70 and greater than Cronbach's alpha values. In addition, the average variance extracted (AVE) values were within the recommended value of $(0.50)$ and above. This suggests that exceeds 0.50 and the total factor load is significant; and therefore, corresponds to the suggested references [77, 76]. The following sections presented data obtained from the measurement model. Results of gender validity (male and female) and reliability for academic performance according to TTF theory has shown in table 2, behavioral intention and actual social media use. The CFA was carried out in the next phase of "the SEM to analyze the proposed hypotheses". All values of Average variance extracted (AVE) and composite reliability (CR), and CA is accepted; therefore, it was found discriminatory validity. In addition, the values have shown in the range and obtained of composite reliability are from .905 to .854 , all of which exceed the limit value of " 0.70 . Added to this, Cronbach's Alpha values ranged between as 0.901 to .864 , all beyond the cut-off value equal to 0.70 . Moreover, average variance extracted (AVE) ranged between 0.719 to .599 " exceeding the proposed value equal to 0.50 . This suggests that the total factor load is negligible and exceeds 0.50, thus, meeting the provided references $[77,76]$. See table 2, figure 2 and figure 3. 
Table 2. Validity and reliability for the male and female students group

\begin{tabular}{|c|c|c|c|c|c|c|c|c|c|c|}
\hline & SC & TEC & TTF & BI & ASMU & SS & PI & AVE & CR & CA \\
\hline SC & .834 & & & & & & & .719 & .854 & .883 \\
\hline TEC & .563 & .940 & & & & & & .678 & .869 & .864 \\
\hline TTF & .445 & .673 & .983 & & & & & .662 & .956 & .876 \\
\hline BI & .673 & .557 & .540 & .896 & & & & .599 & .863 & .895 \\
\hline ASMU & .550 & .660 & .632 & .560 & .890 & & & .702 & .893 & .875 \\
\hline SS & .602 & .529 & .476 & .543 & .640 & .907 & & .700 & .905 & .901 \\
\hline PI & 504 & .437 & .530 & .593 & .642 & .543 & .911 & .692 & .856 & .872 \\
\hline
\end{tabular}

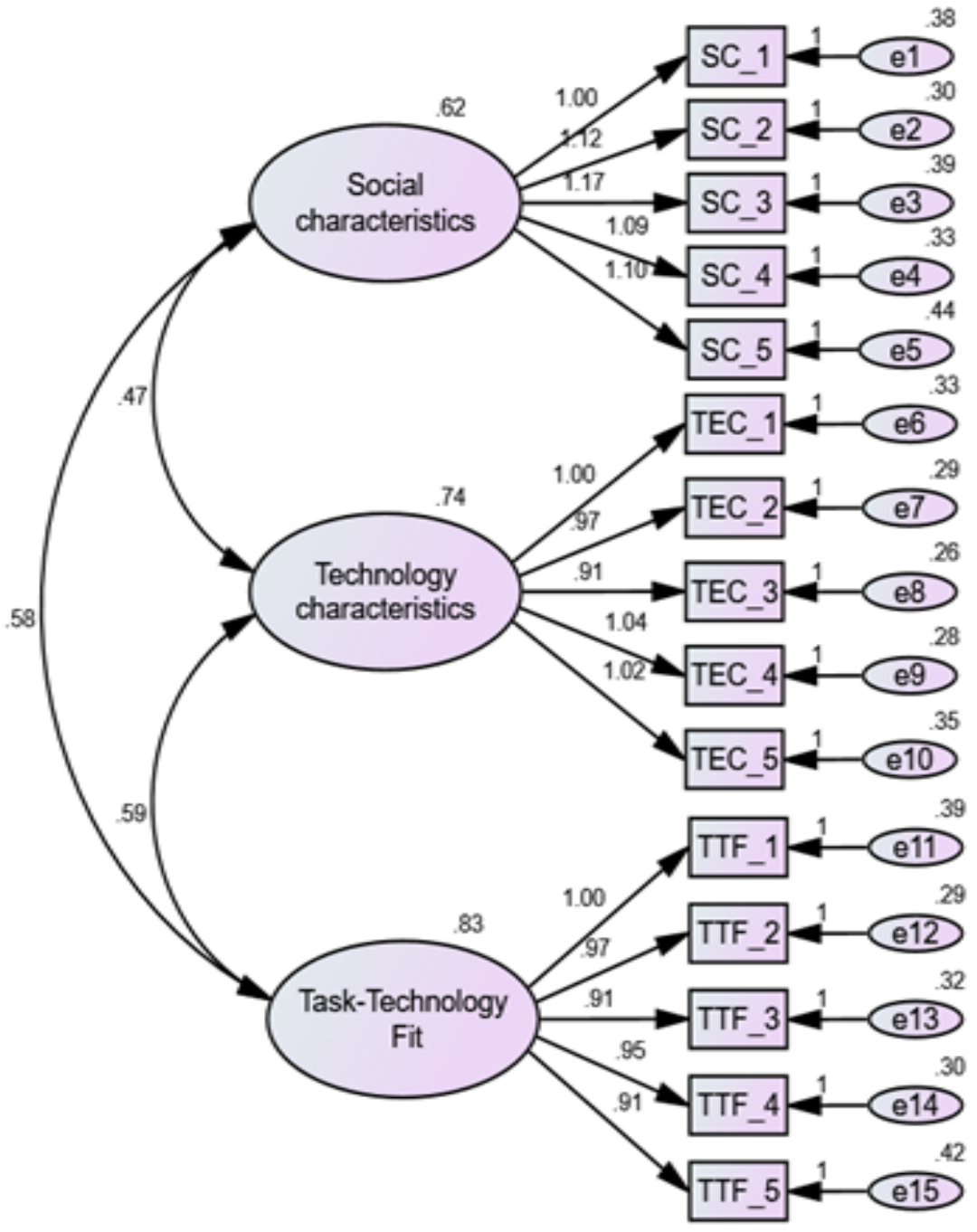

Figure 2. Behavioral intention to use 


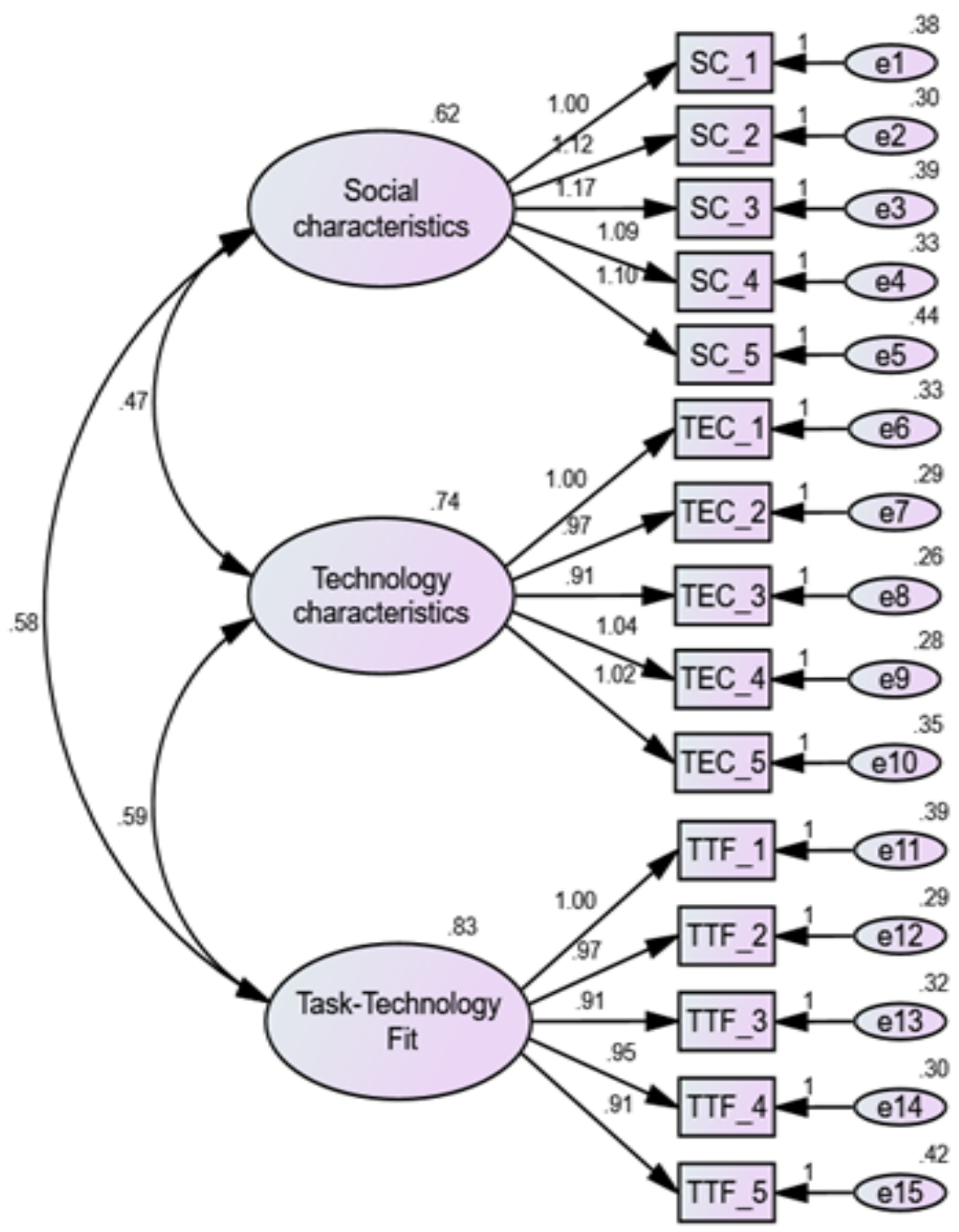

Figure 3. Task technology fit (TTF) Model

\subsection{Structural Model Analysis}

The impact of students' performance use social media tools have studied TTF factors of Behavioral Intention and actual social media use purpose of using social media as students an objective of actual use of social media for teaching on higher education as well as participation of different groups ((male), and female)) by path analysis of modeling. All results have shown based on learning and teaching of students' performance; also, results were compared in the discussion of the hypothesis test. See figure 4.

Figure 4 shows all hypotheses between the ten key constructs the ten hypotheses were accepted hypothesis "social characteristics between male and female students for Task-Technology Fit". both male and female students show that the current sample haven't a social characteristic with peers leads to Task-Technology Fit $(0.50-\mathrm{H} 1)$; both gender groups of male and female students have Technology Characteristics with peers. That's mean, this lead to Task-Technology Fit from Technology Characteristics $(0.38-\mathrm{H} 2)$, and both g male and female students have Task-Technology Fit with peers. That's mean, this lead to behavioral intention to use from Task-Technology Fi $(0.63-\mathrm{H} 3)$; both male and female students have Task-Technology Fit with peers. That's mean, this lead to Actual social media use from Task-Technology Fit (0.44-H4); both male and female students have behavioral intention to use with peers. That's mean, this is lead to Actual social media use from behavioral intention to use $(0.41-\mathrm{H} 5)$, and both gender groups of male and female students have behavioral intention to use with peers. That's mean, this is lead to student satisfaction from behavioral intention to use (0.34-H6), and both gender groups of male and female students have behavioral intention to use with peers. That's mean, this lead to performance impact from behavioral intention to use $(0.38-\mathrm{H} 7)$, and both male and female students have Actual social media use with peers. That's mean, this lead to students' satisfaction from actual social 
media use $(0.45-\mathrm{H} 8)$, and both male and female students have actual social media use with peers. That's mean, this lead to performance impact from Actual social media use (0.17-H9), both male and female students have student satisfaction with peers. That's mean this lead to performance impact from student satisfaction (0.40-H10).

\subsection{Task-Technology Fit Model Hypotheses}

The first direct effect of the Task-Technology Fit theory addressed these assumptions. As below-mentioned in Table 3 and above-mentioned of Figure 4, the relation between correlation Task-Technology Fit is positive through social characteristics " $\beta=.502, t=9.140 p<0.001$ representing that the first hypothesis" (H1) that implies an important and positive relation; in other words, in this hypothesis, it is shown that Task-Technology Fit has social characteristics students to exchanging information with peers or use social media are used appropriately through the exchange of information, discussion. The next step of effect direct is that peers have a significant positive correlation with Technology characteristics, resulting effect to Task-Technology Fit " $\beta=.381, t=6.789 p<0.001$ representing that the second hypothesis" $(\mathrm{H} 2)$ that implies an important and positive relation; in other words, in this hypothesis, it is shown that Task-Technology Fit has Technology characteristics; students' exchanging information with peers or using social media is used through the exchange of information discussion. The next step of effect direct is that peers have a significant positive correlation with Task-Technology Fit, resulting effect to behavioral intention to use " $\beta=.629, \mathrm{t}=12.687 \mathrm{p}<0.001$ representing that the third hypothesis" (H3) ) that implies an important and positive relation; in other words, in this hypothesis, it is shown that all students have Task-Technology Fit with their peers to behavioral intention to use, social media use is used appropriately through the exchange of information, discussion or exchanging information with peers. The next step of effect direct is that peers have a significant positive correlation with Task-Technology Fit, resulting effect to Actual social media use " $\beta=.440, t=7.066 \mathrm{p}<0.001$ representing that the fourth hypothesis" $(\mathrm{H} 4)$ that implies an important and positive relation; in other words, in this hypothesis, it is shown that all students have Task-Technology Fit with their peers to Actual social media use, social media is used appropriately through the exchange of information, discussion or exchanging information with peers, it has shown in table 3 .

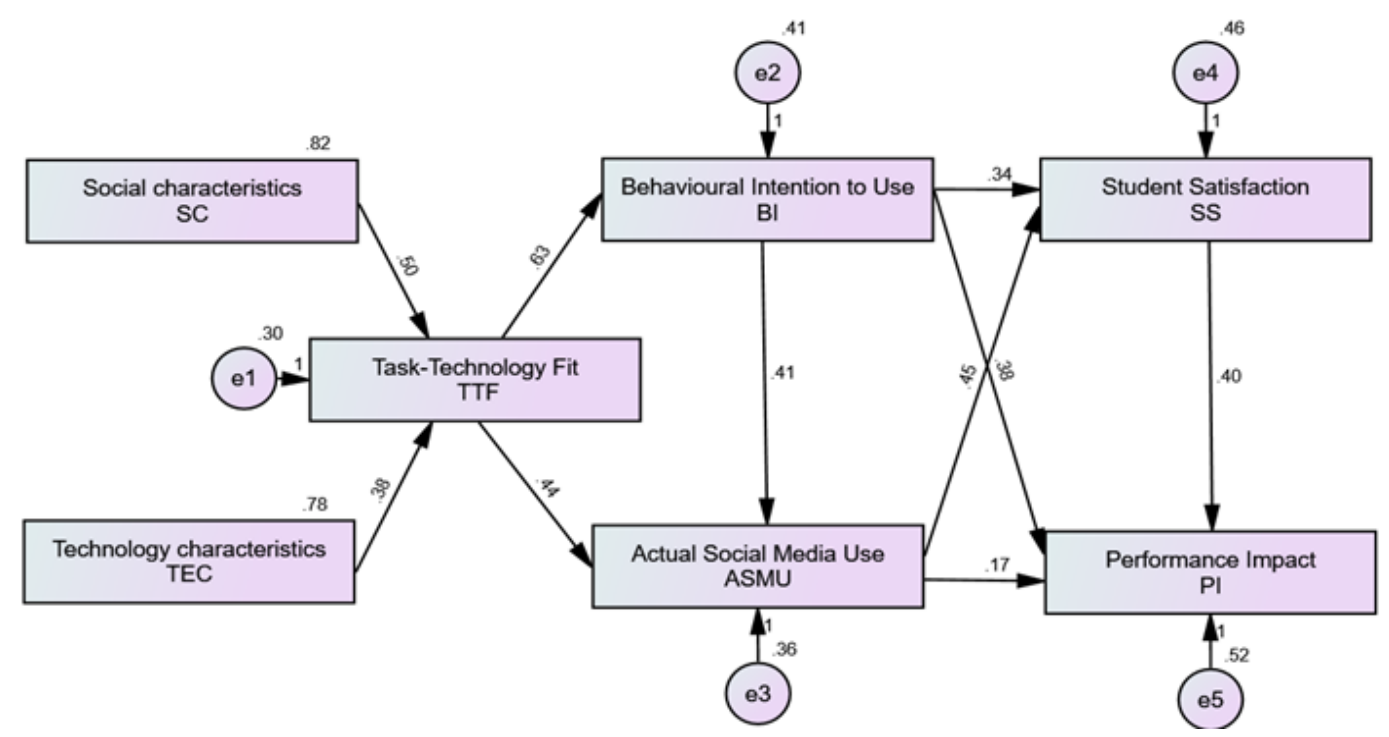

Figure 4. Research Structural Model Analysis

Table 3. Hypothesis testing results of structural model TTF Model

\begin{tabular}{|c|c|c|c|c|c|c|c|c|}
\hline $\mathrm{H}$ & Independent & Relationship & dependent & Estimate & S.E. & C.R. & P & Result \\
\hline $\mathrm{H} 1$ & $\mathrm{SC}$ & $\longrightarrow$ & $\mathrm{TTF}$ & .502 & .055 & 9.140 & $* * *$ & Supported \\
\hline $\mathrm{H} 2$ & $\mathrm{TEC}$ & $\longrightarrow$ & $\mathrm{TTF}$ & .381 & .056 & 6.789 & $* * *$ & Supported \\
\hline $\mathrm{H} 3$ & $\mathrm{TTF}$ & $\longrightarrow$ & $\mathrm{BI}$ & .629 & .050 & 12.687 & $* * *$ & Supported \\
\hline $\mathrm{H} 4$ & $\mathrm{TTF}$ & $\longrightarrow$ & ASMU & .440 & .062 & 7.066 & $* * *$ & Supported \\
\hline
\end{tabular}


Table 4. Hypothesis testing results of structural model behavioral intention to use

\begin{tabular}{|c|c|c|c|c|c|c|c|c|}
\hline & Independent & Relationship & dependent & Estimate & S.E. & C.R. & P & Result \\
\hline $\mathrm{H} 5$ & $\mathrm{BI}$ & $\longrightarrow$ & ASMU & .413 & .066 & 6.295 & $* * *$ & Supported \\
\hline $\mathrm{H} 6$ & $\mathrm{BI}$ & $\longrightarrow$ & $\mathrm{SS}$ & .338 & .075 & 4.492 & $* * *$ & Supported \\
\hline $\mathrm{H} 7$ & $\mathrm{BI}$ & $\longrightarrow$ & $\mathrm{PI}$ & .377 & .083 & 4.524 & $* * *$ & Supported \\
\hline $\mathrm{H} 8$ & $\mathrm{ASMU}$ & $\longrightarrow$ & $\mathrm{SS}$ & .446 & .071 & 6.304 & $* * *$ & Supported \\
\hline $\mathrm{H} 9$ & $\mathrm{ASMU}$ & $\longrightarrow$ & $\mathrm{PI}$ & .171 & .082 & 2.088 & .037 & Supported \\
\hline $\mathrm{H} 10$ & $\mathrm{SS}$ & $\longrightarrow$ & $\mathrm{PI}$ & .398 & .398 & 5.398 & $* * *$ & Supported \\
\hline
\end{tabular}

\subsection{Behavioral Intention to Use Hypotheses}

The next direct effect is that peers have a significant positive correlation with behavioral intention to use, resulting effect to actual social media use " $\beta=.413, \mathrm{t}=$ $6.295 \mathrm{p}<0.001$ representing that the fifth hypothesis" (H5) that's mean an important and positive relation, in other words, in this hypothesis, it is shown that all students have behavioral intention to actual social media use, social networks are used appropriately through the exchange of information, discussion or exchanging information with peers. The next step of direct effect is that peers have a significant positive correlation with behavioral intention to use, resulting effect to students satisfaction " $\beta=.338, \mathrm{t}=$ $4.492 \mathrm{p}<0.001$ representing that the sixth hypothesis" (H6) that implies an important and positive relation, in other words, in this hypothesis, it is shown that all students have behavioral intention to students satisfaction, social networks are used appropriately through the exchange of information, discussion or exchanging information with peers. the next step of direct effect is that peers have a significant positive correlation with behavioral intention to use, resulting effect to performance impact " $\beta=.377, \mathrm{t}=$ $4.524 \mathrm{p}<0.001$ representing that the seventh hypothesis" (H7) that implies an important and positive relation, in other words, in this hypothesis, it is shown that all students have behavioral intention to performance impact, social networks are used appropriately through the exchange of information, discussion or exchanging information with peers. The next step of effect direct is that peers have a significant positive correlation with actual social media use, resulting effect to students satisfaction " $\beta=.446, t=6.304$ $\mathrm{p}<0.001$ representing that the eighth hypothesis" (H8) that implies an important and positive relation, in other words, in the current hypothesis, it is shown that all students have actual social media use to students satisfaction social media are used appropriately through the exchange of information, discussion or exchanging information with peers. The next step of effect direct is that peers have a significant positive correlation with actual social media use, resulting effect to performance impact " $\beta=.171, \mathrm{t}=2.088 \mathrm{p}<0.001$ representing that the ninth hypothesis" (H9) that implies an important and positive relation, in other words, in this hypothesis, it is shown that all students have actual social media use to performance impact, social media are used appropriately through the exchange of information, discussion or exchanging information with peers. The next step of effect direct is that peers has a significant positive correlation with students satisfaction, resulting effect to performance impact " $\beta=.398, \mathrm{t}=5.398 \mathrm{p}<0.001$ representing that the tenth hypothesis" (H10) ) that implies an important and positive relation, in other words, in this hypothesis, it is shown that all students satisfaction with performance impact; social media are used appropriately through the exchange of information, discussion or exchanging information with peers, see table 4 .

\section{Discussion and Implications}

The findings of our study provide insights into student academic success/achievements and relationship between their social characteristics, technology characteristics, task-Technology-Fit, behavioral intention to use social media, actual use of social media, student satisfaction, and performance impact. The use of social media facilitates a context characterized through behavioral intention use of social media and the actual use of social media that helps students practice in clusters to complete tasks rather than successfully complete studies. Based on this research results that use social media conducive atmosphere or a positive that may bring the advancement which is valuable for social characteristics and technology characteristics for Task-Technology-Fit, behavioral intention to utilize social media from Task-Technology-Fit and also actual social media use. Technology characteristics and social characteristics to Develop learning atmosphere by encouraging student and enabling group discussions for task-Technology-Fit as well as completing work or enhance students' performance impact that research projects as proven by research aside from former researches $[28,33]$.The students have social characteristics, Task-Technology-Fit, behavioral intent to utilize, and technology characteristics of obtaining respective peers of 
their essential resources, that means using of social media enhances students' academic activities including directions from mentors. On-campus students recommended that empiric data necessitate greater funding for the use of social media for comparable face-to - face collective discussions $[33,79,80]$. social media allows informative and clarified exchange and also these results in this paper finding is in agreement with another researcher who reported that use social media a positive effect on students' academic activities. This is also usable to the relationship between students with lecturer/supervisor [81, 82]. Meanwhile, this research hypothesis has not been supported through some research concepts; those measure various aspects were validated and could be applied to measures of computer and education human-computer interaction. Also, our researches have another significant theoretical contribution to use social media for knowledge behavioral intent of social media and actual social media use in higher education to increase their educational attainment. This research provides two empirical evidence, first empirical evidence of behavioral intention to use through social characteristics and technology characteristics Task-Technology-Fit, second empirical evidence of actual social media utilize social media as a means of social characteristics and technology characteristics Task-Technology-Fit" which can develop students' educational achievements at higher education. The contents model include "Social characteristics, Technology characteristics, Task-Technology Fit, Behavioral Intention to use, and actual social media use, student satisfaction, and performance impact", which consequently, the students' performance affect in academics at Higher Academic Institutes [28]. Two conclusions are based on the outcomes of this study:

- It is important to using actual social media or behavioral intention to affect educational achievements to inspire students for teaching by use tools of social networking educational achievements as Facebook, Instagram, WhatsApp, and YouTube. In addition, students can support answering inquiries information/ facilitating and sharing of the acquisition of knowledge that enhances researchers' research experiences and promotes learning performance by lecturers and instructors.

- Universities institutes should be encouraged to enroll students for collaborative learning. Social media should be used in the courses other than compelling them to follow orders. By following so, using social media for teaching and learning in higher education can be integrated with all tools and elements of their learning process.

\section{Conclusion and Future Work}

The results of this study affect students' support social characteristics, technological characteristics,
Task-Technology-Fit, and in the end impact their academic performance. The outcomes also presented that turn increases students' behavioural intention to utilize social media through social characteristics, technological characteristics, Task-Technology-Fit for education. Moreover, their academic performance displayed that behavioural intention be utilized to positive influence their education through social media. The use of "Task-Technology Fit theory in examining students' behavioural intention to utilize social to increase academic achievements in higher education has confirmed in the findings". Overall, social media promotes knowledge sharing, facilitates peer discussion, student learning activities, and also information exchange for collaborative learning. This research has provided novel outcomes; however, this research is limitations Sample size was restricted to one university in Malaysia. Therefore, cross-cultural research in broader geographical sample distribution regarding the utilization of social media platforms for education and communication learning might provide findings in more depth for future research. Further studies are recommended to collect data from a larger number of students from multi-institutions in order to enhance and generalize the findings.

\section{REFERENCES}

[1] Chugh, R., Ruhi, U. Social media in higher education: A literature review of Facebook. Education and Information Technologies, 23(2), pp. 605-616, 2018.

[2] Kaplan, A. M., Haenlein, M. Users of the world, unite! The challenges and opportunities of Social Media. Business Horizons, 53(1), pp. 59-68, 2010.

[3] Moafa, F.A., Ahmad, K., Al-Rahmi, W.M., Yahaya, N., Kamin, Y.B., Alamri, M.M. Develop a model to measure the ethical effects of students through social media use. IEEE Access, 6, pp.56685-56699, 2018.

[4] Dumpit, D.Z., Fernandez, C.J. Analysis of the use of social media in Higher Education Institutions (HEIs) using the Technology Acceptance Model. International Journal of Educational Technology in Higher Education, 14(1), pp.1-16, 2017.

[5] Burbules, N.C.,. How we use and are used by social media in education. Educational Theory, 66(4), pp.551-565, 2016.

[6] Lau, W.W. Effects of social media usage and social media multitasking on the academic performance of university students. Computers in human behavior, 68, pp.286-291, 2017.

[7] Alenazy, W.M., Al-Rahmi, W.M. and Khan, M.S.,. Validation of TAM model on social media use for collaborative learning to enhance collaborative authoring. IEEE Access, 7, Pp. 71550-71562, 2019.

[8] Janković, B., Nikolić, M., Vukonjanski, J., Terek, E. The impact of Facebook and smart phone usage on the leisure 
activities and college adjustment of students in Serbia. Computers in Human Behavior, 55, p.354-363, 2016.

[9] Mutohar, A., Hughes, J.E. Toward Web 2.0 integration in Indonesian education: Challenges and planning strategies. In Professional Development and Workplace Learning: Concepts, Methodologies, Tools, and Applications , IGI Global pp. 1867-1884, 2016.

[10] Goodhue, D.L., Thompson, R.L. Task-technology fit and individual performance. MIS quarterly, 2, pp.213-236, 1995.

[11] Piccoli, G., Ahmad, R., Ives, B. Web-based Virtual Learning Environments: A Research Framework and a Preliminary Assessment of Effectiveness in Basic IT Skills Training. Mis Quarterly, 25(4), p. 401-426, 2001.

[12] Akkoyunlu, B., Yilmaz-Soylu, M. A study of student's perceptions in a blended learning environment based on different learning styles. Educational Technology and Society,11(1), p.183-193, 2008.

[13] Ekins, S. Hupcey, M. and Williams, A. Collaborative Computational Technologies for Biomedical Research. John Wiley and Sons, 1, pp. 572-572, 2011.

[14] R. Junco and S. R. Cotten, "No A 4 U: The relationship between multitasking and academic performance," Comput. Educ., 2012. 1.59, (2), pp. 505-514, 2012.

[15] Al-Rahmi, W. M., Yahaya, N., Aldraiweesh, A. A., Alamri, M. M., Aljarboa, N. A., Alturki, U., and Aljeraiwi, A. A. Integrating technology acceptance model with innovation diffusion theory: An empirical investigation on students' intention to use E-learning systems. IEEE Access, 7, p. 26797-26809, 2019.

[16] P. Nemetz, K. D. Aiken, V. Cooney, and V. Pascal, ' Should faculty use social networks to engage with students?' J. Advancement Marketing Educ., 20, (1), p. 19-28, 2012.

[17] W. M. Al-Rahmi, N. Yahaya, M. M. Alamri, N. A. Aljarboa, Y. B. Kamin, and M. S. B. Saud, "How cyber stalking and cyber bullying affect students' open learning, ' IEEE Access, vol. 7, pp. 20199-20210, 2019.

[18] P. A. Kirschner and A. C. Karpinski, "Facebook and academic performance, ' Comput. Hum. Behav., vol. 26, no. 6, pp. 1237-1245, 2010.

[19] C. Madge, J. Meek, J. Wellens, and T. Hooley, "Facebook, social integration and informal learning at university: 'It is more for socialising and talking to friends about work than for actually doing work, ', Learn., Media Technol., vol. 34, no. 2 , pp. 141-155, 2009.

[20] W. M. Al-Rahmi, N. Yahaya, M. M. Alamri, N. A. Aljarboa, Y. B. Kamin, and F. A. Moafa, "A model of factors affecting cyber bullying behaviors among University students, " IEEE Access, vol. 7, pp. 2978-2985, 2018.

[21] A. C. Karpinski, P. A. Kirschner, I. Ozer, J. A. Mellott, and P. Ochwo, "An exploration of social networking site use, multitasking, and academic performance among United States and European university students," Comput. Hum. Behav., vol. 29, no. 3, pp. 1182-1192, 2013.

[22] Lu, H. P., Yang, Y. W. Toward an understanding of the behavioral intention to use a social networking site: An extension of task-technology fit to social-technology fit.
Computers in Human Behavior, 34, 323-332, 2014.

[23] Lin, J. W., and Lin, H. C. K. User acceptance in a computer-supported collaborative learning (CSCL) environment with social network awareness (SNA) support. Australasian Journal of Educational Technology, 35(1), pp.100-115, 2019

[24] Janković, B., Nikolić, M., Vukonjanski, J., and Terek, E. The impact of Facebook and smart phone usage on the leisure activities and college adjustment of students in Serbia. Computers in Human Behavior, 55, pp.354-363, 2016.

[25] Dahri, N. A., Vighio, M. S., and Dahri, M. H. A survey on technology supported collaborative learning tools and techniques in teacher education. In 2019 International Conference on Information Science and Communication Technology (ICISCT), IEEE, pp. 1-9, 2019.

[26] Mutohar, A., Hughes, J. E. Toward Web 2.0 integration in Indonesian education: Challenges and planning strategies. In Professional Development and Workplace Learning: Concepts, Methodologies, Tools, and Applications, IGI Global, pp. 1867-1884, 2016.

[27] J. B. Walther, "Computer-mediated communication: Impersonal, interpersonal, and hyperpersonal interaction," Commun. Res., vol. 23, no. 1, pp. 3-43, 1996.

[28] Wu, B., Chen, X. Continuance intention to use MOOCs: Integrating the technology acceptance model (TAM) and task technology fit (TTF) model. Computers in Human Behavior, 67, 221-232, 2017.

[29] Smith, B. G., Gallicano, T. D. Terms of engagement: Analyzing public engagement with organizations through social media. Computers in Human Behavior,53,pp. 82-9, 2015.

[30] Chiu, H. C., Wang, F. D., Chen, Y. M. A., and Wang, C. T. Effects of human immunodeficiency virus type 1 transframe protein $p 6^{*}$ mutations on viral protease-mediated Gag processing. Journal of general virology, 87(7), pp.2041-2046, 2006.

[31] Lin, K. and Lu, H. Computers in Human Behaviour Why people use social networking sites : An empirical study integrating network externalities and motivation theory. Computers in Human Behaviour. 27(3), pp.1152-1161. 2011.

[32] Tsai, W., Ghoshal, S. Social capital and value creation: The role of intrafirm networks. Academy of management Journal, 41(4), pp. 464-476, 1998.

[33] Lu, H. P., Yang, Y. W. Toward an understanding of the behavioral intention to use a social networking site: An extension of task-technology fit to social-technology fit. Computers in Human Behavior,34, pp.323-332, 2014.

[34] Joo, Y. J., Lim, K. Y., and Kim, E. K. Online university students' satisfaction and persistence: Examining perceived level of presence, usefulness and ease of use as predictors in a structural model. Computers \& education, 57(2), pp.1654-1664, 2011.

[35] Qin, L., Kim, Y., Hsu, J., and Tan, X. The effects of social influence on user acceptance of online social networks. International Journal of Human-Computer Interaction, 27(9), pp. 885-899, 2011. 
[36] Al-Rahmi, W. M., Yahaya, N., Alamri, M. M., Alyoussef, I. Y., Al-Rahmi, A. M., and Kamin, Y. B. Integrating innovation diffusion theory with technology acceptance model: Supporting students' attitude towards using a massive open online courses (MOOCs) systems. Interactive Learning Environments, pp.1-13, 2019.

[37] Mathieson, K., Keil, M. Beyond the interface: Ease of use and task/ technology fit. Information and Management, 34(4),pp. 221-230, 1998.

[38] M. Aljukhadar, S. Senecal and J. Nantel, "Is more always better? Investigating the task-technology fit theory in an online user context", Inf. Manage., vol. 51, no. 4, pp. 391-397, 2014.

[39] Isaac, O., Abdullah, Z., Ramayah, T. and Mutahar, A.M. 'Internet usage within government institutions in Yemen: an extended technology acceptance model (TAM) with internet self-efficacy and performance impact', Science International, Vol. 29, No. 4, pp.737-747, 2017.

[40] Isaac, O., Aldholay, A., Abdullah, Z., Ramayah, T. Online learning usage within Yemeni higher education: The role of compatibility and task-technology fit as mediating variables in the IS success model. Computers \& Education, 136, pp.113-129, 2019.

[41] Venkatesh, V., Morris, M. G., Davis, G. B., and Davis, F. D. User acceptance of information technology: Toward a unified view. MIS quarterly, pp. 425-478, 2003.

[42] Goodhue, D. L., and Thompson, R. L. Task-technology fit and individual performance. MIS quarterly, pp. 213-236, 1995.

[43] Dumpit, D. Z., Fernandez, C. J. Analysis of the use of social media in Higher Education Institutions (HEIs) using the Technology Acceptance Model. International Journal of Educational Technology in Higher Education, 14(1), 5, 2017.

[44] Balakrishnan, V. Key determinants for intention to use social media for learning in higher education institutions. Universal Access in the Information Society, 16(2), pp.289-301, 2017.

[45] Awidi, I. T., Paynter, M., Vujosevic, T. Facebook group in the learning design of a higher education course: An analysis of factors influencing positive learning experience for students. Computers and Education, 129, pp.106-121, 2019.

[46] Cicevic, S., Samcovic, A., Nesic, M. Exploring college students' generational differences in Facebook usage. Computers in Human Behavior, 56, pp.83-92, 2016.

[47] Kim, T. G., Lee, J. H. and Law, R. An empirical examination of the acceptance behaviour of hotel front office systems: An extended technology acceptance model. Tourism Management. 29(3), pp.500-513, 2008.

[48] W.R. King, and J. He, "A meta-analysis of the technology acceptance model”, Information and Management, vol. 43, no. 6, pp. 740-755, 2006.

[49] B. Baran, "Facebook as a formal instructional environment", British Journal of Educational Technology, 41(6), pp. E146-E149, 2010.

[50] Al-Rahmi, W. M., Yahaya, N., Aldraiweesh, A. A., Alturki,
U., Alamri, M. M., Saud, M. S. B., Alhamed, O. A. Big data adoption and knowledge management sharing: An empirical investigation on their adoption and sustainability as a purpose of education. IEEE Access, 7, 47245-47258, 2019.

[51] Alalwan, N., Al-Rahmi, W. M., Alfarraj, O., Alzahrani, A., Yahaya, N., and Al-Rahmi, A. M. Integrated Three Theories to Develop a Model of Factors Affecting Students' Academic Performance in Higher Education. IEEE Access, 7, 98725-98742, 2019.

[52] Sanchez, R.A., Cortijo, V., Javed, U., Students perceptions of Facebook for academic purposes. Comput. Education. 70(1), 138-149, 2014.

[53] Ouhrir, S., S. Lotfi, and M. Talbi. Students' Views on E-learning and Knowledge of Learning Platforms: Case of a Professional License at the Higher Normal School of Casablanca. International Journal of Advanced Trends in Computer Science and Engineering, 8(5): p. 2282-2288, 2019.

[54] Al-Rahmi, W. M., Alzahrani, A. I., Yahaya, N., Alalwan, N., and Kamin, Y. B. Digital Communication: Information and Communication Technology (ICT) Usage for Education Sustainability. Sustainability, 12(12), 5052, 2020.

[55] Olelewe, C. J., Orji, C. T., Osinem, E. C., and Rose-Keziah, I. C. Constraints and strategies for effective use of social networking sites (snss) for collaborative learning in tertiary institutions in nigeria: perception of tvet lecturers. Education and Information Technologies, pp.1-20, 2019.

[56] Cheung, R., \& Vogel, D. (2013). Predicting user acceptance of collaborative technologies: An extension of the technology acceptance model for e-learning. Computers \& education, 63, 160-175.

[57] Mensah, S. O., \& Nizam, I. The impact of social media on students' academic performance-A case of Malaysia Tertiary Institution. International Journal of Education, Learning and Training, 1(1), 14-21, 2016.

[58] Lau, W. W. Effects of social media usage and social media multitasking on the academic performance of university students. Computers in human behavior, 68, 286-291, 2017.

[59] Tang, Y., and Hew, K. F. Is mobile instant messaging (MIM) useful in education? Examining its technological, pedagogical, and social affordances. EducationalResearch Review, 21,pp. 85e104, 2017.

[60] Junco, R., Helbergert, G. and Loken. E. The effect of Twitter on college student engagement and grades. J. Comput. Assist. Lear. 27, pp.119-132, 2011.

[61] Heiberger, G., and Harper, R. Have You Facebooked Astin Lately? Using Technology to Increase Student Involvement. no. 124,pp.19-35, 2008.

[62] J. F. Hair, M. Sarstedt, C. M. Ringle, and J. A. Mena, “An assessment of the use of partial least squares structural equation modeling in marketing research," J. Acad. Marketing Sci., 3, pp. 414-433, 2012.

[63] A. Alzahrani, B. C. Stahl, and M. Prior, "Developing an instrument for e-public services' acceptance using confirmatory factor analysis: Middle east context," J. Organizational User Comput., vol. 24, no. 3, pp. 18-44, 2012 . 
[64] Nahapiet, J., Ghoshal, S. Social capital, intellectual capital, and the organizational advantage. Academy of management review, 23(2), pp.242-266, 1998.

[65] Davis, F. D. Perceived usefulness, perceived ease of use, and user acceptance of information technology. MIS quarterly, pp. 319-340, 1989.

[66] Bere, A., Rambe, P. An empirical analysis of the determinants of mobile instant messaging appropriation in university learning. Journal of Computing in Higher Education, 28(2), 172-198, 2016.

[67] Louw, Jenny, Arthur J. Swart, and Aaron Bere. "Extending the technology acceptance model for e-learning discussion forum adoption." In 6th African Engineering Education Association Conference, Bloemfontein, South Africa.pp,87-92 2016.

[68] Abuhassna, H., et al., Examining Students' Satisfaction and Learning Autonomy through Web-Based Courses. International Journal of Advanced Trends in Computer Science and Engineering, 9(9): p. 356-370, 2020.

[69] Lee, D. Y., Lehto, M. R. User acceptance of YouTube for procedural learning: An extension of the Technology Acceptance Model. Computers \& Education, 61,pp. 193-208, 2013.

[70] Escobar-Rodríguez, T., Carvajal-Trujillo, E. and Monge-Lozano, P. "Factors that influence the perceived advantages and relevance of Facebook as a learning tool: an extension of the UTAUT", Australasian Journal of Educational Technology, 2, pp 2014.

[71] Arthur, J. K., Adu-Manu, K. S and Yeboah, C. A conceptual framework for the Adoption of Social Network Technologies (SNTS) in Teaching - case of Ghana. IJCSI International Journal of Computer Science Issues. 10(5), pp.70-87, 2013.

[72] Owusu-Acheaw, M., and Larson, A. G. Use of social media and its impact on academic performance of tertiary institution students: A study of students of Koforidua Polytechnic, Ghana. Journal of Education and Practice, 6(6), 94-101, 2015.

[73] Goodhue, D. L., Thompson, R. L. Task-technology fit and individual performance. MIS quarterly, pp. 213-236, 1995.

[74] Kim, T. G., Lee, J. H. and Law, R. An empirical examination of the acceptance behaviour of hotel front office systems: An extended technology acceptance model. Tourism Management. 29(3), 500-513, 2008.

[75] Hair, J.F.; Sarstedt, M.; Ringle, C.M.; Mena, J.A. An assessment of the use of partial least squares structural equation modeling in marketing research. J. Acad. Mark. Sci. 40, pp.414-433, 2012.

[76] C. Fornell and D. F. Larcker, "Evaluating structural equation models with unobservable variables and measurement error, ' J. Marketing Res., vol. 18, no. 1, pp. 39-50, 1998.

[77] J. F. Hair, M. Sarstedt, C. M. Ringle, and J. A. Mena, “ $A n$ assessment of the use of partial least squares structural equation modeling in marketing research," J. Acad. Marketing Sci., vol. 40, no. 3, pp. 414-433, 2012.

[78] R. P. Bagozzi, Y. Yi, and K. D. Nassen, "Representation of measurement error in marketing variables: Review of approaches and extension to three-facet designs, ' J. Econ., vol. 89, nos. 1-2, pp. 393-421, 1988.

[79] Goodrum, D. A. Relative Utility Of Three Models For User Evaluations Of Learning Management Systems: A Higher-Ed Institution Decision Context. 2016.

[80] Bere, A. Applying an extended task-technology fit for establishing determinants of mobile learning: an instant messaging initiative. Journal of Information Systems Education, 29(4), 4, pp. 239-252, 2019.

[81] Al-Rahmi, W. M., Yahaya, N., Alturki, U., Alrobai, A., Aldraiweesh, A. A., Omar Alsayed, A., and Kamin, Y. B. Social media-based collaborative learning: the effect on learning success with the moderating role of cyberstalking and cyberbullying. Interactive Learning Environments, Pp.1-14. 2020. DOI: 10.1080/10494820.2020.1728342

[82] M. K. Kabilan, N. Ahmad, and M. J. Z. Abidin, “Facebook: An online environment for learning of English in institutions of higher education?"' Internet Higher Educ.,vol. 13, pp. 179-187, 2010. 